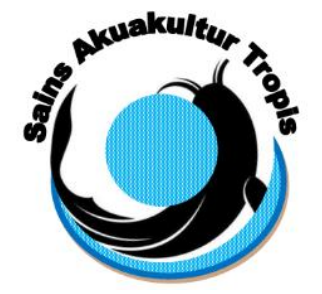

\author{
Jurnal Sains Akuakultur Tropis \\ Departemen Akuakultur \\ Fakultas Perikanan dan Ilmu Kelautan - Universitas Diponegoro \\ JI. Prof. Soedarto, SH, Tembalang, Semarang 50275 \\ Telp. (024) 7474698, Fax.: (024) 7474698 \\ Email: sainsakuakulturtropis@gmail.com, sainsakuakulturtropis@undip.ac.id
}

\title{
PENGARUH PENGKAYAAN Brachionus rotundiformis DENGAN DOSIS VITAMIN (B1, B6, B12 DAN VITAMIN C) BERBEDA DALAM FEEDING REGIMES TERHADAP KELULUSHIDUPAN DAN PERTUMBUHAN LARVA BANDENG (Chanos chanos)
}

\begin{abstract}
The Effect of Enrichment Brachionus rotundiformis with Different Doses Vitamin (B1, B6, B12 and vitamin C) in Feeding regimes to Survival Rate and Growth of Milkfish Larvae (Chanos $\underline{\text { chanos }}$ )
\end{abstract}

\author{
Gina Salsabila, Suminto*), Ristiawan Agung Nugroho \\ Departemen Akuakultur, \\ Fakultas Perikanan dan Ilmu Kelautan, \\ J1. Prof. Soedarto, SH, Tembalang, Semarang, Jawa Tengah -50275, Telp/Fax. +62247474698 \\ * Corresponding author: suminto57@gmail.com
}

\begin{abstract}
ABSTRAK
Ikan bandeng (Chanos chanos) merupakan komoditas perikanan air payau yang sangat potensial untuk dikembangkan dalam budidaya. Produksi larva bandeng dipengaruhi oleh jenis pakan alami rotifer. Peningkatan nutrisi rotifer dapat dilakukan melalui pengkayaan (enrichment) dengan vitamin B1, B6, B12 dan C. Kombinasi vitamin ini diharapkan mampu meningkatkan pertumbuhan dan kelulushidupan larva. Penelitian ini bertujuan untuk mengkaji pengaruh pengkayaan $B$. rotundiformis dengan dosis vitamin (B1, B6, B12 dan C) yang berbeda terhadap kelulushidupan dan pertumbuhan larva. Pengambilan data dilakukan saat larva berusia D3 - D15 dan D15 - D20. Larva D3 dipelihara selama 20 hari di dalam 15 bak plastik yang berisi 30 L air payau dengan kepadatan 600 ekor/bak. Penelitian menggunakan metode eksperimental dengan Rancangan Acak Lengkap (RAL) terdiri atas 5 perlakuan dengan 3 kali pengulangan, yaitu: A (Pengkayaan rotifer $0 \mu \mathrm{g} / \mathrm{ml}$ vitamin B12 dan $0 \mu \mathrm{g} / \mathrm{ml}$ vitamin C), B $(0,7 \mu \mathrm{g} / \mathrm{ml}$ vitamin B12 dan $4 \mu \mathrm{g} / \mathrm{ml}$ vitamin C), C (1,4 $\mu \mathrm{g} / \mathrm{ml}$ vitamin B12 dan $4 \mu \mathrm{g} / \mathrm{ml}$ vitamin C), $\mathrm{D}(2,1 \mu \mathrm{g} / \mathrm{ml}$ vitamin B12 dan $4 \mu \mathrm{g} / \mathrm{ml}$ vitamin $\mathrm{C})$, E $(2,8 \mu \mathrm{g} / \mathrm{ml}$ vitamin B12 dan $4 \mu \mathrm{g} / \mathrm{ml}$ vitamin C). Hasil penelitian menunjukkan bahwa pengkayaan rotifer dengan vitamin B1, B6, B12 dan C berpengaruh sangat nyata $(\mathrm{P}<0,01)$ terhadap Pertumbuhan Panjang Relatif (PPR) dan SR larva D3 - D15 dan berpengaruh sangat nyata $(\mathrm{P}<0,01)$ terhadap EPP, PER, RGR, PPR dan SR larva D15 - D20. Pengkayaan rotifer dengan vitamin B12 1,4 $\mu \mathrm{g} / \mathrm{ml}$ dan vitamin C $4 \mu \mathrm{g} / \mathrm{ml}$ memberikan nilai terbaik pada SR periode pemeliharaan D3 - D15 $(53,11 \pm 0,45 \%)$ pada periode D15 - D20 (96,86 $\pm 0.03 \%)$, sedangkan pengkayaan rotifer dengan vitamin B12 0,7 $\mu \mathrm{g} / \mathrm{ml}$ dan vitamin C $4 \mu \mathrm{g} / \mathrm{ml}$ memberikan nilai terbaik pada EPP $(139,09 \pm 5,954 \%), \operatorname{PER}(3,48 \pm 0,14 \%), \mathrm{RGR}(5,36 \pm 0,22 \% / \mathrm{hari})$ and PPR $(2,94 \pm 0,039 \% /$ hari).
\end{abstract}

Kata kunci: Pengkayaan, Rotifer, Vitamin B1, B6, B12 dan C, Pertumbuhan, Bandeng

\section{ABSTRACT}

Milkfish ( $\underline{\text { Chanos }} \underline{\text { chanos }})$ is high economy a brackish water commodity to culture. Production of milkfish larvae affected live food organism rotifer. Increased rotifer nutrition can be done with enrichment with vitamins B1, B6, B12 and C. Combination of those vitamin hopefully could be increase the growth and survival rate of milkfish larvae. The aim this research was to examine the effect of enrichment $\underline{B}$. rotundiformis with different doses vitamins (B1, B6, B12 and $C)$ on the survival rate and growth of milkfish larvae $(\underline{C} . \underline{\text { chanos }})$. Milkfish larvae of D3 stage was cultured in 15 plastic containers containing 30 L culture media respectively. Those milkfish larvae were cultured during 20 days with initial density of 600 individual every plastic containers. The Completely Randomized Design was applied in this research with 5 treatments and 3 repetitions. Those treatment were $A$ (Enrichment rotifer with $0 \mu \mathrm{g} / \mathrm{ml}$ vitamin $B 12$ and $0 \mu \mathrm{g} / \mathrm{ml}$ vitamin $C), B(0,7 \mu \mathrm{g} / \mathrm{ml}$ vitamin B12 and $4 \mu \mathrm{g} / \mathrm{ml}$ vitamin $C), C(1,4 \mu \mathrm{g} / \mathrm{ml}$ vitamin $B 12$ and $4 \mu \mathrm{g} / \mathrm{ml}$ vitamin $C), D(2,1 \mu \mathrm{g} / \mathrm{ml}$ vitamin $B 12$ and $4 \mu \mathrm{g} / \mathrm{ml}$ vitamin $C)$ and $E(2,8 \mu \mathrm{g} / \mathrm{ml}$ vitamin $B 12$ dan $4 \mu \mathrm{g} / \mathrm{ml}$ vitamin $C)$. The result of this research shows, enrichment rotifer with vitamins B1, B6, B12 and vitamin $C$ with different doses gave significant effect $(P<0.01)$ on the growth of relative weight, growth of relative length and survival rate $(S R)$. The treatment of rotifer enrichment with vitamin B12 of $1,4 \mu \mathrm{g} / \mathrm{ml}$ and $4 \mu \mathrm{g} / \mathrm{ml}$ of vitamin $C$ was given the best dosage on larval SR not only in D3 - 15 culture period 
$(53,11 \pm 0,45 \%)$ but also in D15 - D20 culture period $(96,86 \pm 0.03 \%)$. In the other hand, treatment of rotifer

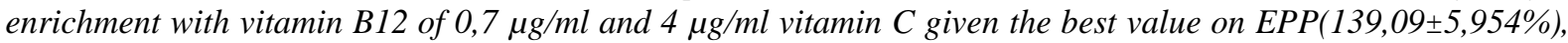
$\operatorname{PER}(3,48 \pm 0,14 \%), \operatorname{RGR}(5,36 \pm 0,22 \% /$ day $)$ and $P P R(2,94 \pm 0,039 \% / d a y)$.

Keyword: Enrichment, Rotifer, Vitamins B1, B6, B12 and C, Growth, Milkfish

Article Received: 05-10-2018; Accepted: 10-01-2019

\section{PENDAHULUAN}

Ikan bandeng merupakan komoditas perikanan yang banyak diminati oleh masyarakat dan sangat potensial untuk dikembangkan dalam kegiatan budidaya. Salah satu permasalahan yang sering dihadapi pada kegiatan budidaya bandeng adalah faktor ketersediaan benih yang berkualitas (Romadon dan Subekti, 2011). Kendala lain adalah tingginya mortalitas dan kondisi fisik larva yang sangat lemah (Gapasin et al., 1998). Hal ini dapat disebabkan karena faktor eksternal (lingkungan dan pakan) dan internal (keturunan). Salah satu solusi untuk memecahkan permasalahan tersebut adalah dengan perbaikan nutrisi pada larva. Pakan adalah nutrisi penting dalam menunjang pertumbuhan dan kelulushidpuan kultivan terutama pada kegiatan pembenihan ikan. Setelah masa kuning telur habis, larva bandeng mutlak memerlukan input pakan dari luar berupa pakan alami. Pakan alami yang telah banyak digunakan untuk pakan larva ikan laut adalah rotifer.

Jenis pakan alami rotifer (Brachionus rotundiformis) dipilih dalam penelitian ini adalah karena rotifer (B. rotundiformis) mempunyai ciri biologi yang memenuhi kriteria pakan yang baik bagi larva bandeng, antara lain ukurannya yang relatif kecil $(100-300 \mu \mathrm{m})$ sesuai dengan bukaan mulut larva, dianggap sebagai biokapsul yang cocok bagi kebanyakan larva laut karena menjadi pentrasfer nutrient dari lingkungan ke larva tanpa efek polutan (Rumengan, 1997). Menurut Kaligis (2015), rotifer sebagai pakan alami bagi larva ikan tidak hanya menyediakan protein dan nutrisi lainnya, tetapi juga dianggap kapsul hidup yang dapat mentransfer mikromolekul dan vitamin bahkan antibiotik ke larva karena sifat rotifer yang filter feeder. Keunggulan lainnya dikemukakan oleh Redjeki (1999), rotifer juga memiliki gerakan yang sangat lambat sehingga mudah ditangkap oleh larva ikan, mudah dicerna, mudah dikultur massal, pertumbuhan dan perkembangannya sangat cepat, tidak menghasilkan racun atau zat lain yang dapat membahayakan kehidupan larva serta memiliki nilai gizi yang paling baik untuk pertumbuhan larva.

Kualitas dan kuantitas rotifer akan ditentukan dari jenis pakan yang diberikan. Peningkatan nutrisi rotifer dapat dilakukan melalui pengkayaan (enrichment). Selain kebutuhan larva ikan laut akan asam lemak essensial, vitamin juga dibutuhkan walaupun dalam jumlah yang sedikit namun tidak kalah penting untuk mencukupi kebutuhan nutrisi tersebut. Pengkayaan rotifer dapat dilakukan dengan menggunakan vitamin B1, B6, B12 dan vitamin C. Kombinasi vitamin B kompleks dan vitamin C merupakan kombinasi yang ideal, sebab vitamin B kompleks dapat membantu sekresi enzim pencernaan sehingga dapat meningkatkan pertumbuhan ikan, defisiensi vitamin B menghasilkan gejala - gejala seperti berkurangnya pertumbuhan dan asupan pakan (anoreksia), dan sebagian besar kekurangan vitamin B menyebabkan gejala anemia (kecuali tiamin) (Hansen, 2015). Menurut Lakani (2015), vitamin C sangat penting untuk perkembangan larva ikan, karena sebagian besar spesies tidak dapat mensintesis vitamin ini. Vitamin $\mathrm{C}$ berperan dalam beberapa proses biologis seperti imunostimulan dan respon stres. Kursistiyanto et al. (2013) menambahkan, kekurangan vitamin C dalam jaringan akan menyebabkan terjadinya pertumbuhan tulang yang tidak sempurna, bahkan dapat sebagai faktor pembatas pertumbuhan bila terjadi defisiensi. Menurut Wolinsky dan Hickson (1998), kinerja vitamin B12 dipengaruhi oleh adanya vitamin C. Kelebihan vitamin C dapat menghambat kinerja dari vitamin B12 di dalam tubuh, hal ini yang kemudian mendasari dosis vitamin $\mathrm{C}$ yang digunakan dalam penelitian ini adalah sama.

Meskipun vitamin dibutuhkan oleh tubuh untuk mencukupi kebutuhan nutrisi, namun kelebihan vitamin dapat memberikan efek negatif. Akumulasi vitamin ini pada keadaan tertentu dapat menyebabkan kondisi beracun atau toksik (hypervitaminosis) (Elango et al., 2015). Sehingga diperlukan penelitian untuk mengetahui dosis vitamin (B1, B6, B12 dan vitamin C) yang tepat untuk meningkatkan kelulushidupan dan pertumbuhan larva bandeng. Beberapa penelitian mengenai pengkayaan rotifer dengan menggunakan jenis vitamin tertentu sudah dilakukan. Salah satunya adalah penelitian yang dilakukan oleh Hirayama dan Satuito (1991), mengenai pengkayaan vitamin B12 dan vitamin $\mathrm{C}$ untuk rotifer namun belum diaplikasikan untuk jenis ikan tertentu. Menurut penelitian yang dilakukan oleh Fernandez et al. (2015), menunjukkan bahwa kadar vitamin C memainkan peran penting pada pertumbuhan dan perkembangan larva ikan laut (Solea senegalensis). Penelitian mengenai penambahan pemberian vitamin B12 pada pakan buatan telah dilakukan oleh Li et al. (2016) pada ikan grass carp, dan Shiau dan Lung (1993) pada ikan nila, namun penelitian pengkayaan rotifer dengan vitamin B1, B6, B12 dan vitamin C dengan dosis yang berbeda untuk larva bandeng belum pernah dilaporkan sebelumnya, hal ini menjadikan topik ini sangat menarik untuk diteliti. 


\section{MATERI DAN METODE}

\section{Pengkayaan Rotifer}

Pengkayaan rotifer dilakukan dengan cara memanen rotifer dari kultur massal yang dilakukan di hatchery bandeng, selanjutnya menyaringnya dengan menggunakan plankton net untuk memisahkan dari kotoran dan agar mendapatkan rotifer dengan ukuran yang lebih kecil. Hasil saringan rotifer (B. rotundiformis) dimasukan kedalam botol air mineral volume 1,5 L kemudian diisi air laut sampai volume $1 \mathrm{~L}$ dan diaerasi, bahan pengkaya ditambahkan kedalam media pengkayaan rotifer. Bahan pengkaya yang digunakan adalah ragi roti dengan dosis $200 \mu \mathrm{g} / \mathrm{ml}$, vitamin $\mathrm{C}$ dengan dosis $4 \mu \mathrm{g} / \mathrm{ml}$ dan vitamin B1, B6 dan B12 dengan dosis sesuai dengan masing masing perlakuan. Pengkayaan dilakukan selama $4-5$ jam.

\section{Persiapan Kultur Bandeng}

Prosedur dalam kultur bandeng meliputi persiapan wadah, penebaran ikan uji dan pemeliharaan larva. Persiapan wadah pemeliharaan meliputi pembersihan, pengeringan wadah dan setting alat. Pengeringan wadah dilakukan selama 1 hari sebelum dilakukan pengisian media kultur bandeng. Setting alat meliputi penempatan wadah pemeliharaan dan pemasangan aerasi pada masing-masing bak pemeliharaan. Penebaran ikan uji dilakukan saat larva berusia D3 dengan kepadatan 20 ekor/L. Larva bandeng didapatkan dari pembenihan di Balai Besar Pengembangan Budidaya Air Payau (BBPBAP), Jepara. Pemeliharaan larva dilakukan selama 20 hari dengan menggunakan bak pemeliharaan berupa wadah plastik kapasitas $50 \mathrm{~L}$ yang diisi air laut $30 \mathrm{~L}$. Pakan uji yang digunakan dalam penelitian ini adalah pakan alami rotifer (B. rotundiformis) dan pakan buatan. Strategi pemberian pakan larva selama penelitian dapat dilihat pada Gambar 1.

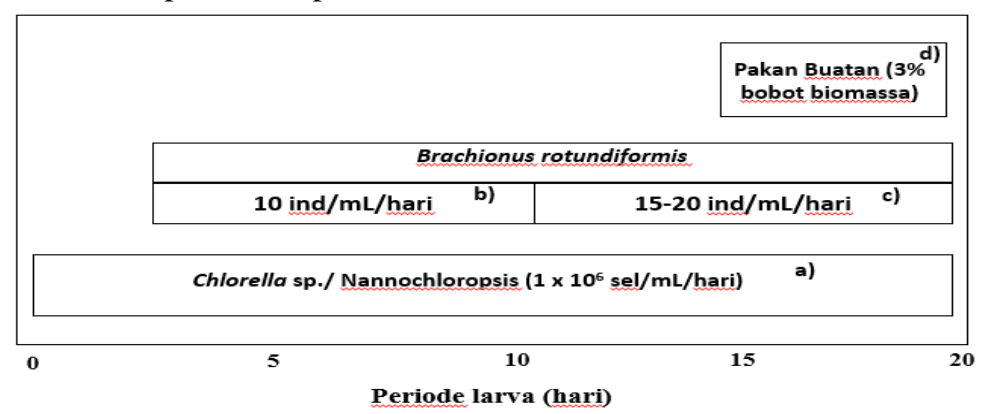

Keterangan:

Gambar 1. Feeding Regimes Larva Bandeng pada Periode Pemeliharaan D20

Dosis pakan alami yang diberikan pada larva bandeng, mengacu pada pustaka:

a) Kusuma dan Andriyono (2012)

b) Duray (1996)

c) Martinez et al. (2006)

d) Kusumawati et al. (2017)

\section{Metode dan Desain Penelitian}

Metode yang digunakan dalam penelitian ini adalah metode eksperimental dengan rancangan percobaan yaitu Rancangan Acak Lengkap (RAL) dengan 5 perlakuan dan 3 kali ulangan dan dilakukan selama 20 hari masa pemeliharaan. Perlakuan dalam penelitian mengacu pada penelitian yang dilakukan oleh Hirayama dan Satuito (1991), yaitu dosis vitamin B12 yang digunakan untuk pengkayaan rotifer adalah $1,4 \mu \mathrm{g} / \mathrm{ml}$ dengan dosis vitamin $\mathrm{C}$ terbaik adalah $4 \mu \mathrm{g} / \mathrm{ml}$. Sehingga perlakuan yang dapat dilakukan dalam penelitian ini adalah perlakuan A : pengkayaan rotifer dengan dosis $0 \mu \mathrm{g} / \mathrm{ml}$ vitamin B 12 dan $0 \mu \mathrm{g} / \mathrm{ml}$ vitamin C, B : pengkayaan rotifer dengan dosis $0,7 \mu \mathrm{g} / \mathrm{ml}$ vitamin B12 dan $4 \mu \mathrm{g} / \mathrm{ml}$ vitamin C, C : Pengkayaan rotifer dengan dosis $1,4 \mu \mathrm{g} / \mathrm{ml}$ vitamin B12 dan 4 $\mu \mathrm{g} / \mathrm{ml}$ vitamin $\mathrm{C}$, D : Pengkayaan rotifer dengan dosis $2,1 \mu \mathrm{g} / \mathrm{ml}$ vitamin B12 dan $4 \mu \mathrm{g} / \mathrm{ml}$ vitamin C, E : Pengkayaan rotifer dengan dosis $2,8 \mu \mathrm{g} / \mathrm{ml}$ vitamin B12 dan $4 \mu \mathrm{g} / \mathrm{ml}$ vitamin C.

\section{Pengumpulan dan Analisa Data}

Pengumpulan data dilakukan saat periode pemeliharaan larva D3 - D15 dan saat periode D15 - D20. Data yang diambil saat periode D3 - D15 adalah Pertumbuhan Panjang Relatif (PPR) dan kelulushidupan (SR), sedangkan saat D15 - D20 data yang diambil meliputi Efisiensi Pemanfaatan Pakan (EPP), Protein Efficiency Ratio (PER), Relative Growth Rate (RGR), Pertumbuhan Panjang Relatif (PPR) dan kelulushidupan (SR). Perhitungan panjang total larva pada awal pemeliharaan (D3) dilakukan dengan menghitung panjang sampel larva sebanyak 30 ekor yang di ambil secara acak dari stok larva yang dipelihara, sedangkan perhitungan panjang total larva pada akhir pemeliharaan (D15 dan D20) dilakukan dengan menghitung panjang sampel larva sebanyak 30 ekor yang di ambil dari setiap ulangan pada masing-masing perlakuan. Pertumbuhan bobot tubuh larva ditimbang menggunakan timbangan analitik dengan ketelitian $0,0001 \mathrm{~g}$ atau $1 \mathrm{mg}$ terhadap 10 ekor sampel yang diambil dari setiap pengulangan dari setiap perlakuan. Bobot tubuh larva ditimbang pada saat larva bandeng D15 dan akhir pemeliharaan D20. Rumus yang digunakan dalam perhitungan adalah sebagai berikut:

Pertumbuhan panjang relatif (PPR) larva bandeng dalam penelitian dihitung dengan menggunakan rumus menurut Efendie (1979), yaitu: 


$$
\mathrm{PPR}=\frac{\mathrm{Lt}-\mathrm{L} 0}{\mathrm{~L} 0 \mathrm{xt}} \times 100 \%,
$$

Keterangan: $\quad$ PPR : Pertumbuhan panjang relatif $(\% /$ hari)

$\mathrm{L}_{\mathrm{t}} \quad$ : Rata - rata panjang total larva pada akhir pemeliharaan (mm)

$\mathrm{L}_{0} \quad$ : Rata - rata panjang total larva pada awal pemeliharaan (mm)

t : Lama waktu pemeliharaan (hari).

Relative Growth Rate (RGR) larva bandeng dihitung dengan menggunakan rumus menurut Efendie (1979), yaitu:

$$
\mathrm{RGR}=\frac{W t-W 0}{W o \times t} \times 100 \%
$$

Keterangan: $\quad$ RGR : Laju pertumbuhan relatif bobot (\%/ hari)

$\mathrm{W}_{\mathrm{t}} \quad$ : Rata - rata bobot larva pada akhir pemeliharaan $(\mathrm{mg})$

$\mathrm{W}_{0} \quad$ : Rata - rata bobot larva pada awal pemeliharaan $(\mathrm{mg})$

$\mathrm{T} \quad$ : Lama waktu pemeliharaan (hari)

Efisiensi Pemanfaatan Pakan (EPP) dihitung dengan menggunakan rumus Tacon (1987), yaitu:

$$
\mathrm{EPP}=\frac{\text { Jumlah pakan yang diberikan }}{\text { penambahan bobot ikan yang dihasilkan }} \times 100 \%
$$

Protein Efficiency Ratio dihitung menggunakan rumus Tacon (1987), yaitu:

$$
\text { PER }=\frac{W t-W 0}{P i} \times 100 \%
$$

$\begin{array}{lll}\text { Keterangan: } & \text { PER } & \text { : Rasio Efisiensi Protein }(\%) \\ & \mathrm{W}_{\mathrm{t}} & \text { : Bobot ikan uji pada akhir penelitian }(\mathrm{g}) \\ & \mathrm{W}_{0} & \text { : Bobot ikan uji pada awal penelitian }(\mathrm{g}) \\ & \mathrm{P}_{\mathrm{i}} & \text { : Berat pakan yang dikonsumsi } \mathrm{x} \% \text { protein pakan }\end{array}$

Kelulushidupan (SR) larva dihitung menggunakan rumus Effendi (1997), yaitu:

$$
\mathrm{SR}=\frac{N t}{N 0} \times 100 \%
$$

$\begin{array}{lll}\text { Keterangan: } & \text { SR } & \text { : Tingkat Kelangsungan Hidup (\%) } \\ & \mathrm{N}_{\mathrm{t}} & \text { : Jumlah individu pada akhir penelitian (ekor) } \\ & \mathrm{N}_{0} & \text { : Jumlah individu pada awal penelitian (ekor) }\end{array}$

Kualitas air yang diamati meliputi suhu, salinitas, oksigen terlarut (DO), dan tingkat keasaman (pH). Pengamatan suhu dilakukan setiap tiga kali sehari yaitu pada pagi, siang dan sore, $\mathrm{pH}$ dan DO dilakukan setiap dua kali sehari yaitu pada pagi dan sore menggunakan alat Water Quality Checker (WQC) dengan cara mencelupkan ujung alat indikator ke dalam air kemudian menunggu hingga konstan dan mencatat nilainya sedangkan salinitas diukur setiap satu hari sekali dengan menggunakan refraktometer.

Data yang dianalisa yaitu data larva bandeng saat D3 - D15 dan D15 - D20. Pengumpulan data dilakukan secara 2 fase menurut feeding regimes larva bandeng. Pada periode pemeliharaan D3 - D15 larva bandeng hanya diberikan pakan alami rotifer yang diperkaya vitamin dengan dosis masing - masing perlakuan, sedangkan pada periode pemeliharaan D15 - D20 larva bandeng diberikan pakan alami dan pakan buatan. Data yang dianalisa yaitu Pertumbuhan Panjang Relatif (PPR) dan kelulushidupan (SR) larva bandeng D3 - D15. Data larva bandeng D15 - D20 yaitu Efisiensi Pemanfaatan Pakan (EPP), Protein Efficiency Ratio (PER), Relative Growth Rate (RGR) dan Pertumbuhan Panjang Relatif (PPR). Data yang diperoleh terlebih dahulu diuji normalitas, uji homogenitas, dan uji additivitas. Selanjutnya dianalisis menggunakan analisis ragam (ANOVA) selang kepercayaan yang digunakan adalah 95\% dan 99\%. Bila perlakuan berpengaruh nyata pada analisis ragam (ANOVA), maka dilanjutkan uji nilai wilayah ganda Duncan untuk mengetahui perbedaan nilai tengah antar perlakuan (Srigandono, 1992).

\section{HASIL}

\section{a. performa pertumbuhan larva bandeng D3 - D15}

Hasil yang diperoleh dari penelitian ini adalah performa pertumbuhan larva bandeng D3 - D15 meliputi Pertumbuhan Panjang Relatif (PPR) dan kelulushidupan (SR) tersaji pada Gambar 2. 


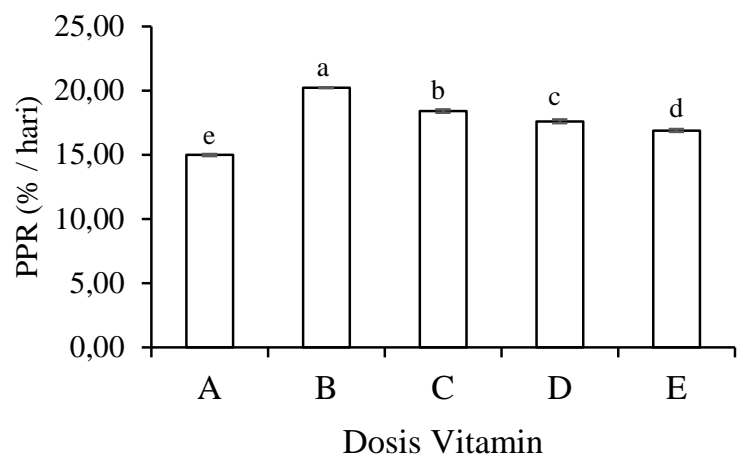

(a)

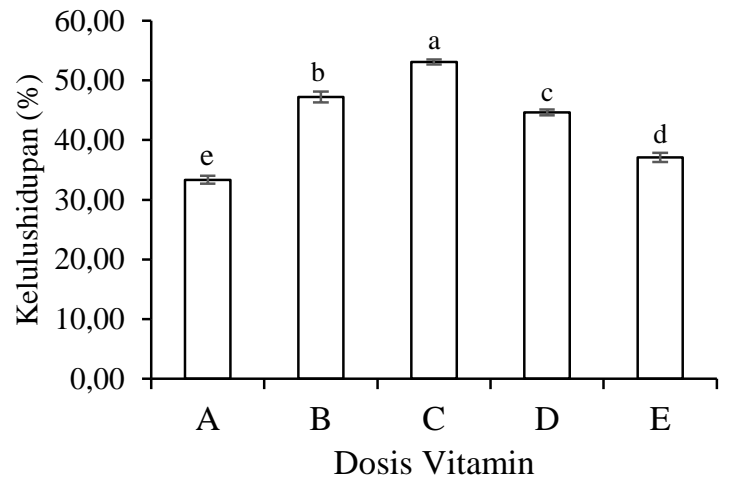

(b)

Gambar 2. Hasil Performa Pertumbuhan Larva Bandeng D3 - D15 (a). Pertumbuhan Panjang Relatif (PPR) dan (b). Kelulushidupan (SR). Nilai supercrip yang berbeda menunjukkan adanya perbedaan yang nyata $(\mathrm{p}>0,05)$

Grafik (2a) diatas menunjukkan bahwa nilai rerata pertumbuhan panjang relatif (PPR) larva bandeng (C. chanos) D3 - D15 pada perlakuan B memberikan pengaruh yang nyata terhadap perlakuan yang lain. Nilai rerata PPR yang tertinggi adalah perlakuan B sebesar 20.21 $\pm 0.14 \%$ /hari, diikuti perlakuan C sebesar $18.40 \pm 0.05 \%$ /hari, perlakuan D sebesar $17.60 \pm 0.26 \%$ /hari, perlakuan E sebesar $16.88 \pm 0.11 \%$ /hari dan terendah pada perlakuan A sebesar 14.97 $\pm 0.14 \%$ /hari. Grafik (2b) menunjukkan bahwa nilai rerata kelulushidupan (SR) larva bandeng (C. chanos) D3 - D15 pada perlakuan C memberikan pengaruh yang nyata terhadap perlakuan yang lain. Nilai rerata SR yang tertinggi adalah perlakuan C yaitu $53.11 \pm 0.42 \%$, diikuti perlakuan B yaitu $44.67 \pm 0.50 \%$, perlakuan D yaitu $44.67 \pm 0.50 \%$, perlakuan E yaitu $37.11 \pm 0.79 \%$ dan terendah pada perlakuan A yaitu $33.33 \pm 0.67 \%$.

\section{b. performa pertumbuhan larva bandeng D15 - D20}

Hasil penelitian performa pertumbuhan dan kelulushidupan larva bandeng D15 - D20 meliputi Efisiensi Pemanfaatan Pakan (EPP), Protein Efficiency Ratio (PER), Relative Growth Rate (RGR) dan Pertumbuhan Panjang Relatif (PPR) dapat dilihat pada Tabel 1.

Tabel 1. Nilai Rerata Efisiensi Pemanfaatan Pakan (EPP), Protein Efficiency Ratio (PER), Relative Growth Rate (RGR), Pertumbuhan Panjang Relatif (PPR) dan kelulushidupan (SR) larva bandeng D15 - D20

\begin{tabular}{ccccccc}
\hline \multirow{2}{*}{ No. } & \multirow{2}{*}{ Variabel Data } & \multicolumn{5}{c}{ Perlakuan } \\
\cline { 3 - 7 } & & $\mathrm{A}$ & $\mathrm{B}$ & $\mathrm{C}$ & $\mathrm{D}$ & $\mathrm{E}$ \\
\hline 1. & EPP (\%) & $68.79 \pm 3.49^{\mathrm{e}}$ & $139.09 \pm 5.94^{\mathrm{a}}$ & $125.91 \pm 3.40^{\mathrm{b}}$ & $106.95 \pm 1.95^{\mathrm{c}}$ & $87.32 \pm 1.28^{\mathrm{d}}$ \\
2. & PER (\%) & $1.75 \pm 0.13^{\mathrm{e}}$ & $3.48 \pm 0.14^{\mathrm{a}}$ & $3.15 \pm 0.09^{\mathrm{b}}$ & $2.65 \pm 0.09^{\mathrm{c}}$ & $2.18 \pm 0.033^{\mathrm{c}}$ \\
3. & RGR (\%/hari) & $3.85 \pm 0.23^{\mathrm{d}}$ & $5.36 \pm 0.22^{\mathrm{a}}$ & $4.93 \pm 0.16^{\mathrm{b}}$ & $4.6 \pm 0.08^{\mathrm{bc}}$ & $4.39 \pm 0.12^{\mathrm{c}}$ \\
4. & PPR (\%/hari) & $2.37 \pm 0.086^{\mathrm{e}}$ & $2.94 \pm 0.039^{\mathrm{a}}$ & $2.808 \pm 0.14^{\mathrm{b}}$ & $2.7 \pm 0.154^{\mathrm{c}}$ & $2.58 \pm 0.116^{\mathrm{d}}$ \\
5. & SR (\%) & $94.99 \pm 0.1^{\mathrm{e}}$ & $96.47 \pm 0.07^{\mathrm{b}}$ & $96.86 \pm 0.025^{\mathrm{a}}$ & $96.27 \pm 0.042^{\mathrm{c}}$ & $95.51 \pm 0.09^{\mathrm{c}}$ \\
\hline
\end{tabular}

Keterangan : Nilai dengan superscript yang sama menunjukkan tidak adanya perbedaan yang nyata.

Tabel 1 menunjukkan nilai rerata hasil performa pertumbuhan dan kelulushidupan larva pada periode pemeliharaan D15 - D20. Data EPP, PER, RGR dan PPR menunjukkan bahwa perlakuan B memiliki perbedaan yang nyata terhadap semua perlakuan. Nilai rerata EPP yang tertinggi didapatkan pada perlakuan B yaitu $139.09 \pm 5.94 \%$, diikuti perlakuan C sebesar $125.91 \pm 3.40 \%$, perlakuan D sebesar $106.95 \pm 1.95 \%$, perlakuan E sebesar $87.32 \pm 1.28 \%$ dan terendah pada perlakuan A sebesar $68.79 \pm 3.49 \%$. Nilai rerata PER yang tertinggi didapatkan pada perlakuan B sebesar 3.48 $\pm 0.14 \%$, diikuti perlakuan C sebesar $3.15 \pm 0.09 \%$, perlakuan D sebesar $2.65 \pm 0.09 \%$, perlakuan E sebesar $2.18 \pm 0.033 \%$ dan terendah pada perlakuan A sebesar $1.75 \pm 0.13 \%$. Nilai rerata RGR yang tertinggi didapatkan pada perlakuan B yaitu 5.36 $\pm 0.22 \%$ /hari, diikuti perlakuan C yaitu $4.93 \pm 0.16 \%$ /hari, perlakuan D sebesar $4.6 \pm 0.08 \%$ /hari, perlakuan E sebesar $4.39 \pm 0.12 \%$ /hari dan terendah pada

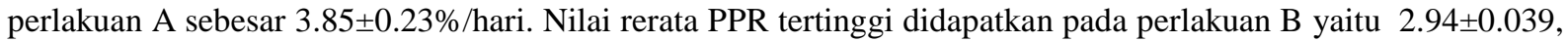
diikuti perlakuan $\mathrm{C}$ yaitu $2.808 \pm 0.1 \%$ /hari, perlakuan $\mathrm{D}$ sebesar $2.7 \pm 0.154 \%$ /hari, perlakuan E sebesar $2.58 \pm 0.116 \%$ /hari dan terendah pada perlakuan A sebesar $2.37 \pm 0.086 \%$ /hari. Data SR menunjukkan bahwa perlakuan $\mathrm{C}$ memiliki perbedaan yang nyata terhadap semua perlakuan. Nilai rerata SR tertinggi didapatkan pada perlakuan C yaitu $96.86 \pm 0.025 \%$, diikuti perlakuan B yaitu $96.47 \pm 0.07 \%$, perlakuan D sebesar $96.27 \pm 0.04 \%$, perlakuan E sebesar $95.51 \pm 0.09 \%$ dan terendah pada perlakuan A sebesar $94.99 \pm 0.1 \%$. 


\section{c. kualitas air}

Parameter kualitas air yang diukur selama penelitian adalah oksigen terlarut, suhu, pH dan salinitas. Hasil pengukuran air selama D3 - D20 serta nilai kelayakannya berdasarkan kajian pustaka tersaji pada Tabel 2.

Tabel 2. Hasil Kualitas Air Pemeliharaan Larva Bandeng (C. chanos) D3 - D20

\begin{tabular}{|c|c|c|c|c|c|c|c|}
\hline \multirow{2}{*}{ Variabel } & \multirow{2}{*}{ Pukul } & \multicolumn{5}{|c|}{ Perlakuan } & \multirow{2}{*}{ Pustaka } \\
\hline & & A & $\mathrm{B}$ & $\mathrm{C}$ & $\mathrm{D}$ & $\mathrm{E}$ & \\
\hline \multirow{3}{*}{ Suhu $\left({ }^{0} \mathrm{C}\right)$} & 08.00 & $29-30$ & $29-30$ & $29-30$ & $29-30$ & $29-30$ & \multirow{3}{*}{$28-32 * *$} \\
\hline & 12.00 & $29-30$ & $29-30$ & $29-30$ & $29-30$ & $29-30$ & \\
\hline & 16.00 & $29-30$ & $29-30$ & $29-30$ & $29-30$ & $29-30$ & \\
\hline $\begin{array}{l}\text { Salinitas } \\
\text { (ppt) }\end{array}$ & & $28-30$ & $28-30$ & $28-30$ & $28-30$ & $28-30$ & $28-35^{*}$ \\
\hline \multirow{2}{*}{$\mathrm{pH}$} & 08.00 & $8,06-8,18$ & $8,06-8,18$ & $8,06-8,18$ & $8,08-8,18$ & $8,08-8,18$ & \multirow{2}{*}{$7-8,5^{* *}$} \\
\hline & 16.00 & $8,06-8,18$ & $8,06-8,18$ & $8,06-8,18$ & $8,06-8,18$ & $8,05-8,18$ & \\
\hline \multirow{2}{*}{$\mathrm{DO}(\mathrm{mg} / \mathrm{L})$} & 08.00 & $5.32-5.64$ & $5.37-5.64$ & $5.29-5.65$ & $5.24-5.65$ & $5.23-5.62$ & \multirow{2}{*}{$\geq 5^{*}$} \\
\hline & 16.00 & $5.43-5.65$ & $5.26-5.63$ & $5.31-5.65$ & $5.29-5.65$ & $5.29-5.62$ & \\
\hline
\end{tabular}

Keterangan:

* : SNI (1999) ** : SNI (2013)

\section{PEMBAHASAN}

\section{a. performa pertumbuhan larva bandeng D3 - D15}

Berdasarkan hasil analisis varian yang telah dilakukan menunjukkan bahwa pengkayaan rotifer (B. rotundiformis) dengan menggunakan vitamin B1, B6, B12 dan vitamin C berpengaruh sangat nyata (P $>0,01)$ terhadap pertumbuhan larva bandeng D3 - D15. Hal ini disebabkan karena pakan alami rotifer yang diberikan telah diperkaya dengan vitamin dan mengandung nutrisi sesuai dengan kebutuhan nutrisi yang dibutuhkan oleh larva bandeng. Menurut Eda et al. (1990), dalam pemeliharaan larva ikan, pemberian pakan dan padat penebaran akan mempengaruhi kelangsungan hidup dan pertumbuhan larva ikan laut. Pertumbuhan juga dipengaruhi lingkungan, keturunan, umur dan penyakit.

Perlakuan B dalam penelitian ini menunjukkan panjang total sebesar $15.053 \pm 0.044 \mathrm{~mm}$ saat larva bandeng D15, hasil ini lebih baik dibandingkan dengan penelitian Aslianti et al. (2012), yaitu panjang total larva yang dipelihara secara indoor yaitu $12,7 \pm 1,1 \mathrm{~mm}$ saat D16. Perlakuan B dalam penelitian ini juga menunjukkan nilai pertumbuhan panjang relatif yang lebih tinggi dibandingkan dengan perlakuan A, C, D dan E, hal ini diduga karena dosis vitamin B12 0,7 $\mu \mathrm{g} / \mathrm{ml}$ yang diberikan sudah mampu untuk menunjang pertumbuhan larva bandeng. Vitamin merupakan zat organik yang dibutuhkan biota budidaya dalam jumlah yang sedikit, tetapi sangat penting untuk mempertahankan pertumbuhan dan pemeliharaan kondisi tubuh. Ikan memerlukan pasokan vitamin B12 dari pakannya dikarenakan microflora intestinenya menghasilkan vitamin B12 dalam jumlah yang kecil. Vitamin B12 merupakan nutrisi penting bagi ikan untuk pertumbuhan dan bermanfaat dalam memperbaiki nafsu makan (Sugita et al., 1994). Hal ini didukung bahwa anorexia (penurunan nafsu makan) umumnya diamati pada berbagai spesies akuatik yang kekurangan vitamin B12 (Hansen et al., 2015).

Perlakuan A (dosis vitamin B12 $0 \mu \mathrm{g} / \mathrm{ml}$ ) dalam penelitian ini menunjukkan nilai pertumbuhan panjang relatif lebih rendah dibandingkan perlakuan lain dengan total panjang $12.23 \pm 0.07 \mathrm{~mm}$. Hal ini diduga karena tidak adanya input vitamin dapat mempengaruhi asupan pakan oleh ikan berkurang, sehingga mengurangi asupan jumlah nutrisi yang diperlukan untuk pertumbuhan tubuh ikan secara maksimum (Li et al., 2016). Menurut Hajar et al. (2016), kekurangan salah satu vitamin akan menyebabkan gejala tidak normal pada ikan sehingga mengganggu proses pertumbuhannya. Oleh karena itu vitamin B12 walaupun dibutuhkan dalam jumlah yang sedikit oleh ikan tetapi fatal jika kekurangan vitamin B12 salah satu dampaknya adalah nafsu makan ikan akan menurun bahkan ikan tidak mempunyai nafsu makan. Menurut Hansen (2015), defisiensi vitamin B1 dapat menyebkan anorexia (penurunan nafsu makan), perubahan warna pada kulit (lebih gelap atau lebih terang dari normal), perubahan perilaku (berenang tidak normal, ataxia), haemorrage, kongesti, nekrosis pada sirip, kulit dan insang, defisiensi vitamin B6 dapat menyebabkan anorexia (penurunan nafsu makan), anemia, perubahan warna pada kulit (lebih gelap atau lebih terang dari normal), perubahan perilaku (berenang tidak normal, ataxia), haemorrage pada intestine, ginjal, hati, pankreas, kulit dan insang, exopthalmia dan oedema pada kulit dn sirip, defisiensi vitamin B12 dapat menyebabkan anorexia (penurunan nafsu makan) dan anemia megaloblastik.

Perlakuan E (dosis vitamin B12 2,8 $\mu \mathrm{g} / \mathrm{ml}$ ) dalam penelitian ini menunjukkan nilai pertumbuhan panjang relatif lebih rendah dibandingkan perlakuan B, C dan D. Hal ini diduga karena pemberian vitamin yang berlebih tidak seluruhnya di serap oleh tubuh ikan, melainkan dikelurkan melalui urin (kecuali vitamin B12). Kelebihan vitamin B12 tidak dapat disintesis dan akan disimpan dalam hepatopankreas. Menurut Shiau dan Lung (1993), tidak seperti vitamin yang larut dalam air lainnya, vitamin B12 dapat disimpan di hepatopankreas dan asupan makanan yang berlebihan dapat menyebabkan overloading vitamin B12 yang dapat menghambat metabolisme dalam jaringan ini. Vitamin yang larut di dalam air (vitamin B kompleks) merupakan kofaktor dalam berbagai reaksi enzimatik yang terdapat di dalam tubuh. Kelebihan vitamin di dalam tubuh akan menimbulkan gejala toksisitas (Rusdiana, 2004). 


\section{c. performa pertumbuhan larva bandeng D15 - D20}

Berdasarkan hasil analisis varian yang telah dilakukan menunjukkan bahwa pengkayaan rotifer rotundiformis) dengan menggunakan vitamin B1, B6, B12 dan vitamin C memberikan pengaruh sangat nyata $(\mathrm{P}<0,01)$ terhadap pertumbuhan panjang relatif dan pertumbuhan bobot relatif larva bandeng, dimana nilai pertumbuhan panjang relatif dan pertumbuhan bobot relatif tertinggi didapatkan pada perlakuan B (dosis vitamin B12 0,7 $\mu \mathrm{g} / \mathrm{ml}$ ), sedangkan pada perlakuan C, D dan E nilai pertumbuhan panjang relatif dan pertumbuhan bobot relatif larva bandeng mulai menurun saat larva diberikan pakan rotifer yang diperkaya dengan vitamin B12 dengan dosis yang lebih tinggi. Hasil ini serupa dengan hasil saat larva bandeng D3 - D15, dimana pertumbuhan panjang relatif tertinggi didapatkan pada perlakuan B. Hal ini diduga dapat mempengaruhi performa pertumbuhan larva saat D15 - D20. Hasil yang serupa juga didapatkan pada penelitian pemberian pakan buatan yang ditambahan dengan vitamin B12 yang dilakukan oleh Li et al. (2016) pada ikan grass carp dan Shiau and Chun (1993) pada ikan nila.

Hal ini juga diduga berhubungan dengan semakin tingginya tingkat efisiensi pemanfaatan pakan, rasio efisiensi protein dan semakin rendahnya rasio konversi pakan larva bandeng D15 - D20. Pada perlakuan B (dosis vitamin B12 0,7 $\mu \mathrm{g} / \mathrm{ml}$ ). EPP yang dihasilkan lebih tinggi dibandingkan perlakuan yang lain sehingga didapatkan pertumbuhan panjang relatif dan pertumbuhan bobot relatif yang lebih tinggi. Efisiensi pemanfaatan pakan mencerminkan penggunaan pakan yang efisien, sehingga hanya sedikit zat makanan yang dirombak untuk memenuhi kebutuhan energi dan selebihnya digunakan untuk pertumbuhan. Faktor yang dapat mempengaruhi pakan terhadap pertumbuhan ikan antara lain aktivitas fisiologi, proses metabolisme dan daya cerna (digestible) yang berbeda pada setiap individu ikan (Handajani dan Widodo, 2010). Peningkatan kinerja pertumbuhan juga dipengaruhi karena adanya input vitamin B1, B6, B12 dan vitamin C dalam pakan alami rotifer. Menurut hasil penelitian Li et al. (2016), peningkatan kinerja pertumbuhan disebabkan karena meningkatnya aktivitas intestinal lipase, protease dan amilase meningkat dengan tajam karena tingkat vitamin B12 dalam pakan meningkat dari 0 hingga $0,12 \mathrm{mg} / \mathrm{kg}$. Ini menunjukkan bahwa mekanisme pencernaan ikan dapat diaktifkan dengan penambahan dosis vitamin B12 yang tepat dalam pakan.

Pertumbuhan panjang relatif dan pertumbuhan bobot relatif pada perlakuan C, D dan E mulai menurun sejalan dengan semakin menurunnya nilai Protein Efficiency Ratio (PER) dan efisiensi pemanfaatan pakan larva bandeng yang mulai menurun saat larva diberikan pakan rotifer yang diperkaya dengan vitamin B12 dengan dosis yang lebih tinggi. Hal ini sesuai dengan penelitian yang dilakukan oleh Li et al. (2016), pada dosis vitamin B12 yang lebih tinggi bobot tubuh ikan pada akhir penelitian (Wt) dan SGR ikan yang diberi vitamin tertinggi menghasilkan nilai yang lebih rendah dibandingkan ikan yang diberikan pakan dengan dosis vitamin B12 sedang. Hal ini diduga karena menurunnya aktivitas intestinal lipase, protease dan amilase sehingga proses pencernaan kurang maksimal. Peningkatan kadar vitamin B12 dalam pakan secara signifikan dapat menurunkan aktivitas intestinal lipase, protease dan amilase sehingga mekanisme pencernaan tidak berjalan dengan baik yang dapat berdampak pada semakin meningkatnya FCR dan akhirnya menghasilkan bobot tubuh ikan pada akhir penelitian (Wt) dan SGR ikan yang lebih rendah (Li et al., 2016).

Hal ini juga diduga karena dosis vitamin B12 yang digunakan sudah melebihi kebutuhan dari larva bandeng sehingga tidak dapat disintesis dan disimpan dalam hepatopankreas. Menurut Shiau dan Lung (1993), tidak seperti vitamin yang larut dalam air lainnya, vitamin B12 dapat disimpan di hepatopankreas kepiting dan asupan makanan yang berlebihan dapat menyebabkan overloading vitamin B12 dalam jaringan, hal ini dapat menjelaskan bahwa dosis vitamin B12 dalam pakan yang berlebihan menyebabkan pertumbuhan kepiting yang lambat. Menurut penelitian yang dilakukan oleh Wei et al. (2014), dosis vitamin B12 terbaik untuk pertumbuhan bobot relatif juvenile kepiting adalah 0,2 dan 0,4 mg vitamin B12/kg pakan buatan. Kepiting yang diberikan pakan tanpa vitamin B12 menunjukkan rendahnya konversi pakan, pertumbuhan dan kematian yang tinggi.

Perlakuan A (dosis vitamin B12 $0 \mu \mathrm{g} / \mathrm{ml}$ ) dalam penelitian ini menunjukkan nilai pertumbuhan panjang relatif dan pertumbuhan bobot relatif lebih rendah dibandingkan perlakuan lain. Hal ini diduga berhubungan dengan tingkat pemanfaatan protein pakan yang rendah sejalan dengan efisiensi pakan larva yang rendah. Defisiensi atau kekurangan vitamin juga dapat menyebabkan dampak negatif bagi ikan. Kekurangan vitamin B12 juga dapat menyebabkan penurunan nafsu makan ikan, hal ini didukung bahwa anorexia (penurunan nafsu makan) umumnya diamati pada berbagai spesies akuatik yang kekurangan vitamin B12 (Hansen et al., 2015). Hal ini akan berdampak negatif pada metabolisme perantara nutrisi dalam ikan, yang akibatnya menghasilkan kinerja pertumbuhan yang rendah/buruk. Kekurangan vitamin B12 dalam pakan juga menyebabkan anemia megaloblastik parah di banyak organisme perairan, yang ditandai oleh eritrosit dan leukosit besar dengan nukleus sel yang terfragmentasi ditambah dengan penurunan konsentrasi hemoglobin dalam darah (Wu et al., 2007; Waagbø, 2010). Selain itu, dapat juga dikaitkan dengan gangguan hemopoiesis (peristiwa pembuatan sel darah merah dan sel darah putih ikan) (Hansen et al., 2015). Hal ini dapat berdampak negatif pada metabolisme perantara nutrisi (Penurunan konsentrasi hemoglobin dalam darah dapat menyebabkan asupan makanan dan oksigen dalam darah tidak dapat diedarkan dengan baik ke seluruh jaringan tubuh) dalam ikan, yang mungkin akibatnya menghasilkan kinerja pertumbuhan yang rendah atau buruk.

\section{d. kelulushidupan (SR)}

Berdasarkan hasil analisis varian yang telah dilakukan menun jukkan bahwa pengkayaan rotifer ( $B$. rotundiformis) dengan menggunakan vitamin B1, B6, B12 dan vitamin C memberikan pengaruh sangat nyata $(\mathrm{P}$ 
$<0,01)$ terhadap kelulushidupan (SR) larva bandeng (C. chanos) saat D3 - D15, dimana kelulushidupan larva bandeng yang tertinggi didapatkan pada perlakuan $C$ yaitu sebesar $53.11 \pm 0.42 \%$, hasil yang hampir sama didapatkan pada penelitian yang dilakukan oleh Aslianti et al. (2012), yaitu SR larva bandeng yang dipelihara secara indoor sebesar $52.78 \pm 11,1 \%$ saat D16. Hasil yang hampir sama ini diduga karena pada penelitian Aslianti et al. (2012), larva bandeng dipelihara secara massal dengan menggunakan wadah berupa bak beton (4 $\mathrm{m}^{3}$ ) sehingga larva bandeng dapat lebih mudah berdaptasi, sedangkan dalam penelitian ini hanya menggunakan wadah plastik volume $50 \mathrm{~L}$ yang diisi air laut $30 \mathrm{~L}$. Hal ini diduga akan mempengaruhi tingkat mortalitas larva yang semakin tinggi karena sifat fisiologis larva bandeng yang mudah beradaptasi sesuai dengan habitat aslinya yaitu di laut lepas.

Perlakuan C menghasilkan SR larva bandeng D3 - D15 yang lebih tinggi dibandingkan dengan perlakuan lain. Hal ini diduga karena pada perlakuan C (dosis vitamin B12 1,4 $\mu \mathrm{g} / \mathrm{ml}$ ) mampu meningkatkan imunitas dan menekan tingkat stress larva sehingga dapat menekan tingkat kematian. Hasil yang serupa juga didapatkan saat larva bandeng D15 - D20, hasil ini diduga dipengaruhi oleh hasil SR saat larva bandeng D3 - D15 dimana SR tertinggi juga didapatkan pada perlakuan C. Hal ini juga diduga karena saat D15 - D20 masih adanya input vitamin B1, B6, B12 dan vitamin C dalam pakan alami rotifer yang masih memberikan efek dalam meningkatkan imunitas dan menekan tingkat stress larva sehingga dapat menekan tingkat kematian larva bandeng. Menurut penelitian yang dilakukan oleh Wei et al. (2014), tingkat pertumbuhan relatif dan kelulusidupan lebih tinggi didapatkan pada perlakuan pakan dengan dosis 0,2 dan $0,4 \mathrm{mg}$ vitamin B12/kg daripada yang diberikan pakan dengan perlakuan yang lain. Hasil ini menunjukkan bahwa penambahan vitamin B12 dalam pakan sangat penting untuk pertumbuhan dan sistem imun non - spesifik ikan. Menurut penelitian Wei et al. (2014), juvenile kepiting yang diberikan pakan dengan 0,2 mg vitamin B12/kg pakan menghasilkan total mortalitas yang terendah karena meningkatnya imun non - spesifik. Hal ini diduga menjadi salah satu alasan penambahan vitamin B12 yang optimal dapat meningkatkan kekebalan tubuh non - spesifik ikan sehingga tingkat kematian dapat ditekan dan menghasilkan kelulushidupan yang tinggi.

Pengkayaan rotifer juga di lakukan dengan menambahkan vitamin $\mathrm{C}$ (dosis $4 \mu \mathrm{g} / \mathrm{ml}$ ) pada setiap perlakuan. Hal ini bertujuan karena vitamin $\mathrm{C}$ merupakan vitamin yang dibutuhkan untuk meningkatkan daya tahan tubuh sehingga dapat mencegah terjadinya stress dan diharapkan dapat meningkatkan kelulushidupan larva. Kombinasi kedua vitamin ini juga diduga dapat meningkatkan kelulushidupan dan pertumbuhan larva bandeng, karena panduan B kompleks dan vitamin C merupakan kombinasi yang ideal. Kedua vitamin tersebut dapat saling melengkapi. Sebab vitamin B kompleks dapat membantu sekresi enzim pencernaan sehingga dapat meningkatkan pertumbuhan ikan (Hansen, 2015). Menurut Kursistiyanto et al. (2013), fungsi vitamin C adalah meningkatkan daya tahan tubuh sehingga mencegah terjadinya stress pada ikan, kekurangan vitamin $\mathrm{C}$ dalam jaringan akan menyebabkan terjadinya pertumbuhan tulang yang tidak sempurna, bahkan dapat sebagai faktor pembatas pertumbuhan bila terjadi defisiensi. Menurut Wolinsky and Hickson (1998), kinerja vitamin B12 dipengaruhi oleh adanya vitamin $\mathrm{C}$, kelebihan vitamin $\mathrm{C}$ dapat menghambat kinerja vitamin B12.

Perlakuan A menunjukkan tingkat kelulushidupan yang lebih rendah dibandingkan perlakuan yang lain baik saat larva bandeng D3 - D15 maupun saat D15 - D20. Hal ini diduga karena tidak adanya input vitamin yang dapat menyebabkan tingkat kematian larva karena kekurangan vitamin dalam tubuh dapat menyebabkan gejala kekurangan atau defisiensi vitamin. Menurut Helver (1972), gejala kekurangan vitamin B kompleks secara umum adalah ikan menderita rangsangan saraf, kehilangan keseimbangan, mata merah, dan berenang tidak normal, yang akhirnya menyebabkan gangguan pada membran sirip dan membran sirip hancur, keluarnya lendir dari tubuh. Menyebabkan mortalitas tinggi 75\% pada ikan mas, dan ikan yang selamat menunjukkan gejala pembengkakan mata. Ikan - ikan yang selamat dapat pulih kembali dalam waktu sekitar 6 hari setelah diberikan injeksi suplemen vitamin B yang terdiri dari piridoksin, pantothenic acid and folic acid, ribovlafin dan cyanocobalamin (B12).

Perlakuan E (dosis vitamin B12 2,8 $\mu \mathrm{g} / \mathrm{ml}$ ) dalam penelitian ini menunjukkan tingkat kelulushidupan larva lebih rendah dibandingkan perlakuan B, C dan D baik saat larva bandeng D3 - D15 maupun saat D15 - D20. Hal ini diduga karena pada fase larva D3 - D15, beberapa organ seperti organ pencernaan sudah mulai terbentuk namun belum sempurna sehingga diperlukan input vitamin B1, B6, B12 dan vitamin C karena salah satu fungsi vitamin B12 adalah meningkatkan kadar hemoglobin pada ikan dan meningkatkan aktivitas enzim pencernaan seperti lipase, amilase dan protease (Li et al., 2016). Meskipun memberikan pengaruh yang nyata terhadap kelulushidupan larva bandeng D15 - D20, namun tingkat kematian tertinggi didapatkan pada saat larva bandeng D3 - D15. Hal ini diduga karena pada larva bandeng D3 organ seperti hati atau hepatopankreas belum sempurna maka larva ikan tidak dapat menerima input dosis vitamin yang terlalu tinggi sehingga tidak dapat disintesis dan dapat menjadi toksik yang menghambat aliran darah dalam tubuh, hal ini dapat menyebabkan kematian pada larva bandeng D3 - D15, karena tidak seperti vitamin yang larut dalam air lainnya, vitamin B12 dapat disimpan di hati atau hepatopankreas hewan air (Shiau dan Lung, 1993; Lin et al., 2010).

Pemberian vitamin yang berlebih menyebabkan kondisi beracun (hypervitaminosis). Berbeda dengan vitamin yang larut dalam air, ikan akan mengakumulasi vitamin B12 di dalam kondisi di mana asupan pakan melebihi kebutuhan metabolik. Akumulasi ini menyebabkan kondisi beracun (hypervitaminosis). Hypervitaminosis merupakan kondisi dimana tingkat penyimpanan vitamin yang tinggi dan tidak normal, hal ini dapat menyebabkan gejala toksik (Elango et al., 2015). Tidak seperti vitamin yang larut dalam air lainnya, vitamin B12 dapat disimpan di hati dan atau hepatopankreas hewan air (Shiau dan Lung, 1993; Lin et al., 2010). Toksisitas vitamin menyebabkan 
pertumbuhan yang berkurang dan hematokrit, nekrosis atau erosi parah pada sirip dubur, ekor, panggul dan dada, skoliosis, lordosis, peningkatan mortalitas, hati kuning pucat, lesu, warna ikan menjadi gelap, efisiensi pakan yang buruk, konsentrasi eritrosit darah berkurang. Menurut Elango et al. (2015), hypervitaminosis B kompleks dalam banyak kasus dapat menyebabkan perubahan warna kulit, ulkus usus, timbunan lemak dalam hati dan gangguan pencernaan. Berbeda dengan larva bandeng D3 - D15, pada periode pemeliharaan D15 - D20 larva sudah mampu beradaptasi dengan lingkungan hidupnya dan semakin hari organ tubuh larva semakin menuju kesempurnaan seperti hal nya organ hati dan hepatopankreas. Hal ini diduga menjadi salah satu hal yang menyebabkan larva bandeng D15 - D20 sudah mampu menyimpan vitamin B12 di dalam hati atau hepatopankreasnya sehingga tingkat mortalitas larva D15 - D20 dapat ditekan dan menghasilkan tingkat mortalitas yang lebih rendah dibandingkan saat periode pemeliharaan larva D3 - D15.

Kelulushidupan larva bandeng selain dipengaruhi oleh faktor pakan alami juga dipengaruhi oleh faktor lain diantaranya adalah umur larva, kualitas air dan penyakit. Menurut Aslianti et al., (2012) sintasan larva dipengaruhi oleh beberapa faktor yaitu lingkungan (kualitas air), pakan (alami dan buatan), kualitas telur, hama dan penyakit. Kualitas air media pemeliharaan larva bandeng masih dalam kisaran kelayakan sehingga dapat mendukung kelulushidupan larva.

\section{KESIMPULAN DAN SARAN \\ Kesimpulan}

Kesimpulan yang dapat diperoleh dari penelitian ini adalah:

1. Pengkayaan rotifer dengan menggunakan vitamin B1, B6, B12 dan vitamin C berpengaruh sangat nyata $(\mathrm{P}<0,01)$ terhadap Pertumbuhan Panjang Relatif $(\mathrm{PPR})$ dan kelulushidupan $(\mathrm{SR})$ larva bandeng periode pemeliharaan D3 - D15.

2. Pengkayaan rotifer dengan menggunakan vitamin B1, B6, B12 dan vitamin C berpengaruh sangat nyata $(\mathrm{P}<0,01)$ terhadap Efisiensi Pemanfaatan Pakan (EPP), Protein Efficiency Ratio (PER), Relative Growth Rate (RGR), Pertumbuhan Panjang Relatif (PPR) dan kelulushidupan (SR) larva bandeng D15 - D20.

3. Perlakuan $\mathrm{C}$ (pengkayaan rotifer dengan dosis $1,4 \mu \mathrm{g} / \mathrm{ml}$ vitamin $\mathrm{B} 12$ dan $4 \mu \mathrm{g} / \mathrm{ml}$ vitamin $\mathrm{C}$ ) memberikan nilai terbaik yaitu pada SR periode larva D3 - D15 sebesar 53,11 $\pm 0,45 \%$ dan pada periode larva D15 - D20 sebesar $96.86 \pm 0.03 \%$, sedangkan perlakuan B memberikan nilai terbaik pada PPR larva bandeng periode D3 - D15 sebesar 20,21 $\pm 0,08 \%$ /hari dan menghasilkan EPP, PER, RGR dan PPR periode pemeliharaan larva D15 - D20 yaitu masing - masing sebesar 139,09 $\pm 5,954 \%, 3,48 \pm 0,14 \%, 5,36 \pm 0,22 \% /$ hari dan $2,94 \pm 0,039 \% /$ hari.

\section{Saran}

Saran yang dapat disampaikan dari penelitian ini adalah sebaiknya pada hatchery bandeng dapat menerapkan pengkayaan rotifer dengan menggunakan vitamin B1, B6, B12 (dosis 1,4 $\mu \mathrm{g} / \mathrm{ml}$ ) dan vitamin C (dosis $4 \mu \mathrm{g} / \mathrm{ml}$ ) sebelum rotifer diberikan untuk pakan larva.

\section{Ucapan Terimakasih}

Terima kasih penulis ucapkan kepada Bapak Ir. Abidin Nur, M.Sc. selaku pembimbing di Balai Besar Pengembangan Budidaya Air Payau (BBPBAP), Jepara yang telah memberikan fasilitas selama penelitian, serta Bapak Agus dan Mas Yadi yang telah membantu selama penelitian di lapangan, sehingga penulis dapat menyelesaikan penelitian ini.

\section{DAFTAR PUSTAKA}

Aslianti, T., A. Nasukha dan A. Priyono. 2012. Peningkatan Kualitas dan Produksi Benih Ikan Bandeng Chanos chanos Forsskal Melalui Perbaikan Manajemen Pemeliharaan Larva. Balai Besar Penelitian dan Pengembangan Budidaya Laut Gondol. Prosiding Indoaqua - Forum Inovasi Teknologi Akuakultur, 117 $-125 \mathrm{hlm}$.

Duray, M. N. 1996. Larviculture of Milkfish (Chanos chanos) in Outdoor Tanks. Journal SEAFDEC Aquaculture, pp. $149-157$.

Eda, H., Murashige, R. Eastham., B. Wallace, L. Wallace., P. Bass., C. S. Tamaru and C. S. Lee. 1990. Survival and Growth of Milkfis (Chanos chanos) Larvae in the Hatchery I. Feeding. Aquaculture, 89: 233 - 244.

Effendi, M. I. 1979. Metoda Biologi Perikanan. Penerbit Yayasan Agromedia. Bogor. 58 hlm.

Elango, G., D. D. Venkataraman, S. Venkata Rao and V. S. Ravi Kiran. Hypervitaminosis. International Journal of Biomedical Research, 6(03): 151 - 154.

Fernandez, E. J., M. Ponce., A. R. Rua., E. Zuasti., M. Manchado and C. F. Diaz. 2015. Effect of Dietary Vitamin C Level during Early Larval Stages in Senegalese Sole (Solea senegalensis). Aquaculture, 443: $65-76$.

Gapasin, R. S. J., R. Bombeo, P. Lavens, P. Sorgeloos and H. Nelis. 1998. Enrichment of Live Food with Essential Fatty Acids and Vitamin C: Effect on Milkfish (Chanos chanos) Larval Performance. Aquaculture, 162: $269-286$. 
Hajar, S., M. Asfie dan C. A. Pebrianto. 2016. Studi Bakteri Aeromonas Penghasil Vitamin B12 pada Intestine Ikan Gabus (Channa Striata). Jurnal Sains dan Teknologi Akuakultur, 2(2): 1 - 10.

Handajani dan Widodo. 2010. Nutrisi Ikan. Umm Press, Malang. $271 \mathrm{hlm}$.

Hansen, A. C., Waagbø, R., Hemre, G. I. 2015. New B Vitamin Recommendations in Fish When Fed Plant - Based Diets. Aquaculture Nutrition, 21: 507-527.

Helver, J. E. 1972. Fish Nutrition. Academic Prea, Inc. London. 711p.

Hirayama, K and C. G. Satuito. 1991. The Nutritional Improvement of Baker's Yeast for the Growth of the Rotifer, Brachionus plicatilis. Rotifer and Microalgae Culture Systems. Proceedings of a U.S. - Asia, pp. 152 162.

Kaligis, E., Y. 2015. Viabilitas Rotifer (Brachionus rotundiformis) Strain Meras pada Suhu dan Salinitas Berbeda. Jurnal LPPM Bidang Sains dan Teknologi, 2(1): 25 - 33.

Kusuma, S. A dan S. Andriyono. 2013. Manajemen Pemberian Pakan Alami, Nannochloropsis oculata dan Rotifera pada Pemeliharaan Larva bandeng (Chanos Chanos Forskal) di CV. Dwi Jaya Buleleng - Bali. Journal of Marine and Coastal Science, 1(3): $22 \mathrm{hlm}$.

Kursistiyanto, N., S. Anggoro dan Suminto. 2013. Penambahan Vitamin C pada Pakan dan Pengaruhnya Terhadap Respon Osmotik, Effisiensi Pakan dan Pertumbuhan Ikan Nila Gesit (Oreochromis sp.) pada Media dengan Osmolaritas Berbeda. Jurnal Saintek Perikanan, 8(2): 66 - 75.

Kusumawati, D., Z. Jamaris dan T. Aslianti. 2017. Profil Pertumbuhan, Enzimatis, dan Nutrisi Ikan Bandeng (Chanos chanos) Generasi Kedua (G2) Terseleksi dengan Menerapkan Standar Operasional Prosedur (SOP) Pemeliharaan Larva. Media Akuakultur, 12(2): 55 - 66.

Lakani, F. B. 2015. Dietary vitamin C Requirements in Fish Larvae. Journal First International Larviculture Conference in Iran, $117-123 p$.

Li, X - F., F. Wang, Y. Qian, G - Z. Jiang, D. D Zhang and W - B Liu. 2016. Dietary Vitamin B12 Requirement of Fingerling Blunt Snout Bream Megalobrama amblycephala Determined by Growth Performance, Digestive and Absorptive Capability and Status of the GH - IGF - I Axis. Aquaculture 464. 647 - 653.

Lin, Y. H., J. Y. Wu and S. Y. Shiau. 2010. Dietary Cobalt can Promote Gastrointestinal Bacterial Production of Vitamin B12 in Sufficient Amounts to Supply Growth Requirements of Grouper, Epinephelus malabaricus. Aquaculture, 302: 89 - 93.

Martinez, F. S., M. Tseng and S. P. Yeh. 2006. Milkfish (Chanos chanos) Culture: Situations and Trends. Journal Fish Society of Taiwan, 33(3): 229 - 244.

Redjeki, S. 1999. Budidaya Rotifera. Jurnal Oseana, XXIV(2): 27 - 43.

Romadhon, A. dan E. Subekti. 2011. Teknik Budidaya Ikan Bandeng di Kabupaten Demak. MEDIAGRO, $7(2): 19-24$.

Rumengan, I. F. M. 1997. Rotifer Laut (Brachionus spp.) sebagai Biokapsul bagi Larva Berbagai Jenis Fauna Laut. WIPTEK UNSRAT, 19: $34-43$.

Rusdiana. 2004. Vitamin. USU Digital Library. Fakultas Kedokteran, Universitas Sumatera Utara. $11 \mathrm{hlm}$.

Shiau, S. Y. and C. Q Lung. 1993. No Dietary Vitamin B12 Required for Juvenile Tilapia Oreochromis niloticus x Aureus. Comp. Biochem Physial. 105A(1):147 - 150.

Shiau, S. Y. and C.Q Lung., 1993b. Estimation of the Vitamin B12 Requirements of Grass Shrimp, Penaeus monodon. Aquaculture, 117: 157-163.

SNI. 1999. Produksi Benih Ikan Bandeng (Chanos chanos Forskal) Kelas Benih Sebar. 15 hlm.

SNI 6148.3. 2013. Ikan Bandeng (Chanos chanos Forskal) Bagian 3: Produksi Benih. 9 hlm.

Srigandono, B. 1992. Rancangan Percobaan. Fakultas Peternakan, Universitas Diponegoro, Semarang, 178 hlm.

Sugita, H., A. Kuruma, C. Hirato, T. Ohkosi, R. Okada, dan Y. Deguchi. 1994. The Vitamin B12 Producing Bacteria in the Water and Sediment of a Carp Culture Pond. Aquaculture, 119: 425 - 431.

Tacon. A.G. J. 1987. Nutrition and Feeding of Farmed Fish and Shrimp, Goverment Cooperative Progamme (FAO). Brasil. $79-80$ hlm.

Waagbø, R. 2010. Water - Soluble Vitamins in Fish Ontogeny. Aquaculture Research, 41: 733 - 744.

Wei, J., N. Yu, W. Tian, F. Zhang, Q. Wu, E. Li., M. Zang, Z. Du., Z Qin and L.Chen. 2014. Dietary vitamin B12 Requirement and its Effect on Non - Specific Immunity and Disease Resistance in Juvenile Chinese mitten crab Eriocheir sinensis. Aquaculture, 434: 179 - 183.

Wolinsky, I. and Hickson, J. P. 1998. Advanced Nutrition Micronutrients. 219 p.

Wu, F. H., M. Wen, Z. Jiang, A. Zhao, 2007. Effects of Dietary Vitamin B12 on Growth, Body Composition and Hemopoiesis of Juvenile Grass Carp (Ctenopharyngodon idellus). Journal Jilin Agricultural University, 29: 695-699. 